мова XVII-XVIII століть. Зібрані прачі / зібрав і до друку підготував Володимир Пилипович. Перемишль, 2016. С. 98-110.

6. Приступа П.І. Рефлекси давнього наголошеного ъ на території західних говорів української мови. Дослідження $i$ матеріали 3 української мови. Київ, 1961. Т 4. С. 145-154.

7. Рабош Г. Адаптація як одна 3 передумов іншомовних запозичень. Вісник Львівського університету. Серія міжнародні відносини. 2017. Випуск 42. С. 327-334.

8. Стаменова А. История лексических древнеболгаризмов в украинском литературном языке. София, 2017. 536 с.

DOI https://doi.org/10.30525/978-9934-26-073-5-1-10

\title{
НОМІНАТИВНІ МОДЕЛІ РІЗНОВИДІВ КОШАР У ГУЦУЛЬСЬКОМУ ГОВОРІ УКРАЇНСЬКЇ МОВИ
}

\author{
Пашкова Н. I. \\ кандидат філологічних наук, доиент, \\ дочент кафедри української філології та славістики \\ Київського національного лінгвістичного університету \\ м. Київ, Украӥна
}

Гуцульщина - український етнічний ареал, розташований на східних схилах Карпат. У силу природних умов землеробство тут поступилося скотарству, найбільш поширений тут відгінний тип вівчарства, коли худоба півроку випасається на гірських полонинах. Отже, найбільш популярною архітектурною формою н полонинському господарстві $\epsilon$ кошара: 1) »загорода або хлів для овець, кіз; вівчарня»; рідко «хлів для великої рогатої худоби»; 2) перен. «будь-яке приміщення, переповнене людьми»; 3) »дерев'яний фабричний будинок», «житловий будинок для робітників біля фабрики тощо» [6, т. IV, с. 315].

У монографії «Гуцульщина. Лінгвістичні етюди» у записі 1956 p. М. Грицака у с. Росішка Рахівського р-ну Закарпатської обл. введено у науковий обіг 15 оригінальних ендемічних назв різновидів кошар, які нижче класифіковано за номінативними моделями.

Дериваційно-метонімічна локативна модель «місце - дім». Локацією мотивована гуцульська назва легкої тимчасової споруди піддеревка, що має таке тлумачення у діалектологічному записі: «Коли віуці лиш так 
спля під деревом, шо лиш так мало їх обмечут хашчеу, аби ся ни розходили, то така кошара - піддереука» [4, с. 284].

Дериваційно-метонімічна темпоративна модель «часовий відрізок дім». Лексему зимарка «Словник української мови» тлумачить із позначкою діал. як «місце зимівлі» 3 ілюстрацією 3 твору І. Франка «зимарка - в Гуиульщині хата в полонинах» [6, т. III, с. 566]. Б. Грінченко цитує В. Шухевича, визначаючи назву зимарка як «зимова хата в полонині, без печі, в ній живуть робітники, які годують худобу, що там стоїть» [2, т. II, с. 151]. Автори історико-етнографічної праці «Гуцульщина» пояснюють діалектні назви зимівка, зимарка як «приміщення для зимування худоби та збереження запасів сіна на полонинах» [3, с. 163], записано також «зиміука - то комара, де зимуюь віуиі» [4, с. 284]. П. Гриценко наводить діалектні назви зимник, земник «приміщення для волів, корів, коней» серед болгарсько-українських паралелей [1, с. 214], пор. також срб. зимиште, зимовник «зимній випас», «місце зимівлі» [7, с. 156]. Отже, за наявними матеріалами досліджувану лексему можна кваліфікувати як південно-східнослов'янську паралель, твірною основою цього темпоратива $\epsilon$ псл. *zima [5, т. II, с. 262].

Відповідно від назв сезонів утворені гуцульські різновиди кошар: «Веснярька - тото усі кошари, шо ся у них находит весновишче. Усі кошари, шо у них перебувйе літовишче - літнярька. Осеніука ся зве осіння кошара» [4, с. 284).

Ізоглоса актуалізаторів темпоративної номінативної моделі продовжується на теренах румунської мови та їі діалектів, де відомий термін iarnatic «місце зимівлі пастухів і стада», утворений від iarnă «зима» та tomnatic «осінне пасовище» - відповідно від tоатпӑ «осінь», (пор. назву гори Тимнатик у Воловецькому р-ні Закарп. обл., яку народна етимологія помилково пов'язує з прикметником темний). За аналогічною моделлю утворена також від слов'янської основи назва весняного пасовища Веснатик у Воєводині. Слід зазначити, що, зважаючи на етнічну строкатість цієї країни, лексема Веснатик цілком могла бути зафіксована в україномовному анклаві.

Дериваційно-метонімічна квалітативна модель «матеріал - дім». На Гуцульщині виявлено ендемічний різновид кошари, що називається тут воринянка: «Що з вориня кочара, то воринянка» [4, с. 284]. Назва мотивована найменуванням матеріалу - діалектним гуцульським словом вориння, воринє - «жердяна огорожа, частокіл, кілля» [5, т. I, с. 403].

Також наводиться ще один гуцульський різновид кошари, мотивований назвою матеріалу: «3 пруття кошара - прутянка. 
Прутянки май більше там чинили, бо тото май скоро мож учинити» [4, c. 284].

Ще один гуцульський різновид кошари, мотивований матеріалом сториянка. "Сториянка звеся кошара з сториовиня, з лемешіу. Тепер май білше кошари чиня сториовані» [там само].

Дериваційно-метонімічна каузативна модель «дія - дім». Гуцульський ендемічний конструктивний різновид кошари мав назву заруб: «Комара була ни городжена, ай зарубана, заруб» [там само].

Тимчасова споруда для овець мала на Гуцульщині й оригінальну віддієслівну назву обгород, обгородка: «Каждий газда парує обгород на віуиі тай на ягнята. Обгородка - тото лии на одну ніч» [там само].

На Гуцульщині вживався також віддієслівний ендемізм пригородок на позначення спеціального приміщення для овець під час доїння, тобто у значенні більш поширеного слова струнка: «Пригородок робля на доєня, аби віуиі ни тікали під кошароу» [там само].

Дериваційно-метонімічна фінітивна модель «функція - дім». Назва мішалка записана $з$ таким поясненням: «Мішалка - то така кошара, де з многих околіу мішають віуиі, коли здоя на міру» [там само]. Ця ендемічна гуцульська назва різновиду кошари етимологічно прозора, віддієслівна, утворена на слов'янському грунті.

Плекарка - гуцульський ендемізм на позначення приміщення для малих ягнят. Назву утворено від дієслова плекати румунського походження, що означає «доглядати, виховувати, опікуватися». «Коло хліва гійа пекарку чинити плекати ягнята» [там само].

Притулок - гуцульська автохтонна назва слов'янського походження 3 прозорою віддієслівною етимологією, див. притула. «Притулок - тото лиш таке намало, аби було де ся притулити, мало лиш перебути з худобов» [там само].

Дериваційно-метонімічна пропрієтативна модель «мешканець дім». На Гуцульщині відома назва баранарька - «саме така кошара на барани» [4, с. 284].

Окремим різновидом кошари на Гуцульщині є хроманиця. «Як $\epsilon$ много хромань, то городя окреме кошару и на них - хроманиџю, аби їх ни місили здорові віуціі» [там само].

Так само мотивована назва янчарька - «кошара на ягнята» [там само].

У гуцулів окіл - «обгороджене місце для доїння овець», «кошара» [3, с. 178], «кошара перед доїльною стрункою» [4, с. 284], okiw «загороджене місце круглої форми для рогатої худоби» [8, т. II, с. 221], Автори «Етимологічного словника української мови» наводять таку 
семантику української лексеми окіл, оків, окол: «загорожа для овець перед доїнням», «кругла огорожа 3 кілків», «загорожа для худоби», форми околище «місце, де була огорожа для овець» та відповідники у П., ч., слвц., схв., слн. мовах. Стсл. околь «коло» походить від псл. *okolb «кругла огорожа, окружність», префіксованого деривата, пов'язаного 3 kolo [5, т. IV, с. 169]. Отже, лексема утворена за віддієслівною каузативною моделлю від околити «обгородити довкола», що підтверджують зафіксовані на всьому ареалі значення «огорожа».

Назву холодарка записано 3 тлумаченням: «така кошара, шо около $\epsilon$ холод аби мали де ся сховати віуиі від сония або дожджу» [4, с. 284].

\section{Література:}

1. Гриценко П. Ю. Ареальне варіювання лексикия. Київ: Наукова думка, 1990. 272 с.

2. Грінченко Б. Д. Словарь української мови: в 4 т. Київ: Вид-во АН УРСР, 1958.

3. Гуцульщина. Історико-етнографічне дослідження / укл. П. І. Арсенич, М. І. Базак, 3. Є. Болтарович та ін. Київ : Наукова думка, 1987. $471 \mathrm{c}$.

4. Гуцульщина. Лінгвістичні етюди. Київ : Наукова думка, 1991. $306 \mathrm{c}$.

5. Етимологічний словник української мови : у 7 т. / за ред. О. С. Мельничука та ін. Київ : Наукова думка, 1982-2012.

6. Словник української мови: в 11 т. / за ред. І. К. Білодіда. Київ: Наукова думка, 1971-1980.

7. Толстой И. И. Сербскохорватско-русский словарь. Москва : Русский язык, 1982.737 с.

8. Шухевич В. Гуцульщина. Матеріяли до українсько-руської етнольогії. Ч. I-V Львів: НТШ, 1899-1908 